УДК [811.161.2+811.111+811.112.2]:[164.2:159.9.019.4]

DOI https://doi.org/10.32841/2409-1154.2021.50-1.18

Кінащук А. B.,

аспірантка кафбедри романо-германської білологї

Рівненського державного гуманітарного університету

\title{
АКТАНТИ ТЕМАТИЧНОЇ ГРУПИ ПРЕДИКАТІВ НА ПОЗНАЧЕННЯ ІРРАЦІОНАЛЬНОЇ ПОВЕДІНКИ В УКРАЇНСЬКІЙ, АНГЛІЙСЬКІЙ ТА НІМЕЦЬКІЙ МОВАХ
}

\begin{abstract}
Анотація. У статті розглянуто предикатно-актантні моделі як один із засобів презентації семантичної структури лексики в контексті функціонального синтаксису. У дослідженні представлено тематичну групу предикатів на позначення ірраціональної поведінки в українській, англійській і німецькій мовах. Описано центральні елементи ядерної семантичної структури, уточнено поняття предиката та актанта 3 позиції функціонального синтаксису. У роботі проаналізовано семантичні ролі учасників ірраціональної ситуації, з-поміж яких виокремлено учасників Зміст та Експерієнцер. Охарактеризовано актанти Зміст та Експерієнцер відповідно до наведених прикладів в українській, англійській і німецькій мовах для досліджуваної тематичної групи предикатів у зіставному аспекті. Актанти Зміст та Експерієнцер проаналізовано відповідно до їхнього синтаксичного вираження, комунікативного рангу й таксономічного класу в семантичній структурі ірраціональної лексики української, англійської та німецької мов. 3'ясовано, що приклади виокремлених семантичних ролей учасників наявні в кожній із зазначених мов. Актанти Зміст та Експерієнцер відрізняються своїм синтаксичним вираженням (приналежністю до різних частин мови або поєднанням різних частин мови в одному словосполученні, різними видами синтаксичного зв'язку в реченні) в українській, англійській та німецькій мовах. Встановлено, що комунікативний ранг і таксономічний клас проаналізованих актантів Зміст та Експерієнцер збігаються в мовах, що порівнюються. Визначено та проаналізовано особливості реалізації предикатно-актантних відношень для тематичної групи предикатів на позначення вияву ірраціонального стану в межах ірраціональної ситуації в українській, англійській і німецькій мовах. Окреслено перспективи подальших досліджень семантичних структур ірраціональної лексики стосовно вивчення специфікаторів названої тематичної групи ірраціональних предикатів в українській, англійській та німецькій мовах.

Ключові слова: предикатно-актантні відношення, предикатно-актантне моделювання, функціональний синтаксис, семантична роль, синтаксична роль, синтаксичне вираження, комунікативний ранг, таксономічний клас.
\end{abstract}

Постановка проблеми. На сьогодні функціональний синтаксис у мовознавстві розглядають як один із розділів лінгвістичної науки, який досліджує мову з позиції структурного вивчення ситуацій, семантичних ролей та елементів ситуації. До питання функціонального синтаксису зверталися у своїх роботах Ю. Апресян [1], О. Падучева [2], О. Деменчук [3] та інші науковці. На матеріалі споріднених і неспоріднених мов дослідники з різних країн прагнуть з'ясувати особливості реалізації когнітивної діяльності людини в аспекті предикатно-ак- тантних моделей. Актуальність представленої роботи полягає в антропоцентричній тенденції мовознавчих досліджень споріднених та неспоріднених мов у сучасному мовознавстві.

Аналіз останніх досліджень і публікацій. У руслі функціонального синтаксису провадили свої дослідження А. Залізняк (вивчення предикатів внутрішнього стану) [4], О. Десюкевич (розгляд внутрішньої та зовнішньої семантики дієслів соціальних відносин) [5], Ю. Варфоломєєва (класифікація дієслівних предикатів зорової перцепції в розмовному описі) [6] та інші автори. Також дослідники вивчали в зіставному аспекті специфічні лексико-тематичні групи різних мов щодо формування класифікації предикатів емоційного стану у французькій, англійській і німецькій мовах (Г. Ленько) [7], розглядали динамічні моделі перцептивної лексики на матеріалі української, польської та англійської мов (О. Деменчук) [3], досліджували предикати страху в англійській, російській і французькій мовах (I. Варуха) [8] тощо. Здобутки науковців цього напряму свідчать про актуальність розвідок із функціонального синтаксису не лише стосовно дослідження предикатно-актантних моделей усередині однієї мови, а й у зіставному аспекті.

У роботі представлено зіставний аналіз актантів предикатів тематичної групи на позначення ірраціональної поведінки (зокрема, ірраціональної мовленнєвої діяльності) в українській, англійській та німецькій мовах. Об'єктом дослідження $€$ предикати названої тематичної групи в зіставлюваних мовах, наприклад: укр. заговорюватися, химерити, марити; англ. talk rubbish, talk nonsense, talk though one's hat, prate; нім. irre redden, fiebern, delirieren, fantasieren.

Мета статті - охарактеризувати актанти тематичної групи предикатів на позначення ірраціональної поведінки в українській, англійській та німецькій мовах.

Для досягнення поставленої мети в дослідженні необхідно виконати такі конкретні завдання:

- уточнити поняття предиката та актантів із позиції функціонального синтаксису;

- охарактеризувати актанти досліджуваної тематичної групи предикатів у зіставному аспекті;

- описати особливості предикатно-актантних відношень ірраціональних предикатів у досліджуваних мовах;

- визначити перспективи подальших досліджень ірраціональної лексики.

Предметом дослідження $є$ предикатно-актантні відношення тематичної групи предикатів на позначення ірраціональної поведінки в українській, англійській і німецькій мовах. Об'єктом дослідження слугували дібрані методом суцільної вибірки 10 дієслів (3 з української мови, 3 з англійської мови, 
4 з німецької мови), що належать до семантичного класу ірраціональної лексики.

Як основні методи в дослідженні використано описовий, зіставний і метод моделювання. Описовий метод уможливлює систематизацію та узагальнення зібраної інформації й фактичного матеріалу. За допомогою зіставного методу проаналізовано специфіку представлення предикатно-актантних відношень в українській, англійській та німецькій мовах. Для формування предикатно-актантних моделей застосовано метод моделювання. Сукупність вказаних методів забезпечує достовірність висновків та об'єктивність отриманих результатів.

Виклад основного матеріалу дослідження. За А. Мустайокі, опис моделі функціонального синтаксису базується на семантичних структурах, які відображають стан справ та коментарі того, хто говорить про цей стан справ [9, с. 412]. При цьому ядро семантичної структури, на думку дослідника, $€$ ii центральним елементом, складниками якого є предикат та актант. Під предикатом розуміємо логічний складник висловлювання, який наділений істинним значенням цього висловлювання та визначає відносини суб' єкта 3 іншими складниками семантичної структури. Аналіз предикатів видається неможливим без аналізу також супутніх із ними актантів. Актант у дослідженні тлумачимо як учасника ситуації, що заповнює валентність предиката за певною семантичною роллю та вступає у відповідні цій ролі відношення з предикатом. Основними учасниками ірраціональної ситуації досліджуваної тематичної групи є учасники Експерієнцер та Зміст. Учасник Експерієнцер представлений як такий, що сприймає (відчуває, розуміє) інформацію та в певний спосіб опрацьовує іiі (зокрема, виражає іiі мовленнєво), наприклад: укр. Ганна подумала, щзо баба

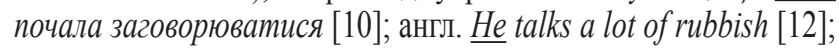
нім. Während des Fieberschubs redete er irre [11]. Учасника Зміст тлумачимо як певну інформацію (повідомлення), яке сприймає (відчуває, промовляє, розуміє) Експерієнцер, наприклад: укр. Добре було б дати сюди підбори, передок $i$ закоти з малинової шкіри, - химерив Омелько, розглядаючи замшу [10]; англ. Inevitably there's some caller prating on about the decline in moral standards [13]; нiм. Ein ehemaliger Wächter Elsers fantasiert über gemeinsame Fluchtpläne aus Sachsenhausen [11]. Охарактеризуємо кожну із семантичних ролей ситуації, послуговуючись відповідними прикладами.

В українській мові в ситуації «ірраціональна мовленнєва діяльність» учасник Експерієнцер займає позицію підмета: укр. За день жар збільшився, i Кривоніс почав уже заговорюватися [14]. Синтаксично такий актант може бути виражений:

- іменником: укр. Люди почали заговорюватися [авт.];

- вказівним займенником: укр. Чи не почав той часом заговорюватися з горя [10];

- особовим займенником: укр. Ніби засинала, тоді вона марила [10];

- морфологічною формою дієслова: укр. Але стала химерити, щовечора мучила мене: «Чи вернеться до нас той чоловік, мамо?» [10].

За комунікативним рангом такий учасник ситуації належить до Центру уваги. Експерієнцера характеризуємо за таксономічним класом ЛЮДИНА: укр. Володимир почав уголос марити [10].

В англійській мові в ситуації «ірраціональна мовленнєва діяльність» Експерієнцер також займає позицію підмета: англ.
Is it just me or was she talking nonsense in the meeting? [13]. Синтаксично такий учасник може бути виражений:

- іменником: англ. People who talk about authentic costume are talking rubbish [15];

- особовим займенником: англ. He's talking rubbish [12];

- наказовим способом дієслова: англ. Don't talk rubbish! [12].

За комунікативним рангом актант Експерієнцер належить до Центру уваги. Такого учасника характеризуємо також за таксономічним класом ЛЮДИНА: англ. Lejb Abrahamovich was talking nonsense at the river again [16].

У німецькій мові в ситуації «ірраціональна мовленнєва діяльність» Експерієнцер, як і в українській та англійській мовах, також займає позицію підмета: нім. Der Kranke fantasierte die ganze Nacht [17]. Синтаксично такий учасник може бути виражений:

- іменником: нім. Immer, immer ..., ob die Fürsten delirieren oder nicht [11];

- особовим займенником: нім. Fantasierst $\underline{d u}$ (redest $d u$ Unsinn), oder sagst du die Wahrheit? [17];

- морфологічною формою дієслова: нім. Phantasieren, sich lebhaften Vorstellungen überlassen, auch s.v.w. delirieren [11].

За комунікативним рангом учасник Експерієнцер належить до Центру уваги. Цього актанта характеризуємо також за таксономічним класом ЛЮДИНА: нім. Um neun Uhr fing Caspar an zu delirieren [11].

В українській мові учасник Зміст у ситуації «ірраціональна мовленнєва діяльність» займає позицію прямого додатка: укр. Але стала химерити, щовечора мучила мене: „Чи вернеться до нас той чоловік, - ие про тебе, - навішо він нам, ти мене не покинеш, мамо?» [10]. Синтаксично такий учасник може бути виражений:

- простим реченням: укр. Добре було б дати сюди підбори, передок $і$ закоти з малинової шкіри, - химерив Омелько, розглядаючи замшу [10];

- складнопідрядним реченням: укр. Подихавши киснем, він знову почав марити - вимовляв слова, яких син ніколи не чув $\underline{\text { вid HbOго }}$ [10];

- безсполучниковим реченням: укр. Але стала химерити, щовечора мучила мене: «Чи вернеться до нас той чоловік, - ие про тебе, - навішо він нам, ти мене не покинеш, мамо?» [10].

За комунікативним рангом актант Зміст належить до Центру уваги. Учасника Зміст характеризуємо за такими таксономічними класами:

- ДІЯ: укр. Добре було б дати сюди підбори, передок i закоти з малинової шкіри, - химерив Омелько, розглядаючи замmy [10];

- ЗДАТНІСТЬ: укр. Але стала химерити, щовечора мучила мене: «Чи вернеться до нас той чоловік, - ие про тебе, - навішо він нам, ти мене не покинеш, мамо?» [10];

- ІНФОРМАЦІЯ: укр. Подихавши киснем, він знову почав марити - вимовляв слова, яких син ніколи не чув від нього [10].

В англійській мові в ситуації «ірраціональна мовленнєва діяльність» актант Зміст також займає позицію прямого додатка: англ. Inevitably there's some caller prating on about the decline in moral_standards [13]. Синтаксично такий учасник ситуації може бути виражений сполученням прийменника, іменника та прикметника. За комунікативним рангом учасник Зміст належить до Центру уваги. У дослідженні для актанта Зміст виокремлюємо таксономічний клас ПОДІЯ: англ. Inevitably there's some caller prating on about the decline in moral_standards [13]. 
У німецькій мові в ситуації «ірраціональна мовленнєва діяльність» учасник Зміст також займає позицію прямого додатка: нім. Ein ehemaliger Wächter Elsers fantasiert über gemeinsame Fluchtpläne aus Sachsenhausen, während ein SS-Mann aus Dachau meint, endlich die „Wahrheit" über Elsers Tod zu enthüllen [11]. Синтаксично такий учасник може бути виражений сполученням прийменника та іменника. За комунікативним рангом актант належить до Центру уваги. Учасника Зміст характеризуємо за таксономічним класом ІНФОРМАЦИЯ.

Висновки. Таким чином, у статті уточнено поняття предиката (як складника, що визначає відношення суб'єкта 3 іншими складниками семантичної структури) та актанта (учасник, що заповнюе валентність предиката за певною семантичною роллю). В українській, англійській та німецькій мовах предикатно-актантні моделі тематичної групи предикатів на позначення ситуації «ірраціональна мовленнева діяльність» презентують учасників Експерієнцер і Зміст. Предикатно-актантні відношення досліджуваної тематичної групи засвідчують явище ірраціональності як таке, що виявлясться як певна інформація (Зміст), яку сприймає та мовленнєво виражає учасник Експерієнцер.

Перспективи подальших розвідок щодо ірраціональної лексики вбачаємо в зіставному вивченні специфікаторів для досліджуваної тематичної групи предикатів в українській, англійській і німецькій мовах.

\section{Лimepamypa:}

1. Апресян Ю. Фундаментальная классификация предикатов и системная лексикография. URL: https://iling.spb.ru/typo/materials/ gc03pdf/apresjan_spb2003.pdf (дата звернення: 17.08.2021).

2. Падучева Е. Динамические модели в семантике лексики. Москва : Языки славянской культуры, 2004. 608 с.

3. Деменчук О. Динамічні моделі перцептивної лексики (на матеріалі української, польської та англійської мов). Філологічні студї. 2014. Вип. 11. С. 39-46.

4. Зализняк А. Исследования по семантике предикатов внутреннего состояния. Мюнхен : Verlag Otto Sagner, 1992. 203 с.

5. Десюкевич О. Внутренняя и внешняя семантика глаголов социальных отношений (на материале русских глаголов победы и поражения). Acta Universitatis Lodziensis. 2019. № 18. С. 71-83.

6. Варфоломеева Ю. Классификация глагольных предикатов зрительной перцепции в разговорном описании. Филология: научные исследования. 2018. № 3. С. 98-104.

7. Ленько Г. Классификация предикатов эмоционального состояния на материале французского, английского и немецкого языков. URL: https://www.hse.ru/data/2013/11/25/1336990285/\%D1\%81\%D $1 \% 82 \% \mathrm{D} 0 \% \mathrm{~B} 0 \% \mathrm{D} 1 \% 82 \% \mathrm{D} 1 \% 8 \mathrm{C} \% \mathrm{D} 1 \% 8 \mathrm{~F} \% 203$.pdf (дата обращения: 16.08.2021).

8. Варуха И. Предикаты страха в английском, русском и французском языках : автореф. дисс. ... канд. филол. наук : 10.02.19. Уфа, 2011. $22 \mathrm{c}$.

9. Мустайоки А. Теория функционального синтаксиса. Москва : Языки славянской культуры, 2006. 512 с.

10. Корпус української мови. URL: http://www.mova.info/corpus.aspx (дата звернення: 22.03.2020).
11. Digitales Wörterbucher der Deutschen Sprache. URL: https://www.dwds.de/ (Datum der Bewerbung: 22.03.2021).

12. The Free Dictionary: Dictionary, Encyclopedia and Thesaurus. URL: https://www.thefreedictionary.com/ (access date: 22.03.2021).

13. Cambridge Dictionary. URL: https://dictionary.cambridge.org/ru (access date: 16.08.2021).

14. Словник української мови : в 11 т. / за ред. І. Білодіда. URL: http://sum.in.ua/ (дата звернення: 22.03.2020).

15. Longman. URL: https:/www.ldoceonline.com/dictionary/ go-run-flash-etc-through-somebody-s-mind (access date: 12.08.2021).

16. Reverso. Context. URL: https://context.reverso.net (access date: 12.08.2021).

17. Die deutsche Rechtschreibung. URL: https://www.duden.de/ (Datum der Bewerbung: 12.08.2021).

Kinashchuk A. Actants of the thematic group of predicates to define irrational behavior in the Ukrainian, English and German languages

Summary. The study presents predicate-actant modeling as one of the means to present the semantic structure of vocabulary in the context of functional syntax. The author singles out the group of predicates to denote the irrational behavior in the Ukrainian, English and German languages. It has been described central elements of the core semantic structure. The research specifies the notion of predicate and actant in the aspect of functional syntax. The paper reveals semantic roles of participants of irrational situation that are presented with the participants of Experiencer and Content. The study characterizes the actant Content and the actant Experiencer according to their presentation in the Ukrainian, English and German languages for researched thematic group of predicates in the comparative aspect. The actants Content and Experiencer have been analyzed according to their syntactical expression, communicative rank and taxonomic class in semantic structure of irrational vocabulary in the Ukrainian, English and German languages in the comparative aspect. The study presents examples of outlined semantic roles of the participants in each of the chosen languages. The actants Content and Experiencer differ with their syntactical expression (belonging to different parts of speech or combining different parts of speech in one word combination or different kinds of syntactical link in a sentence) in the Ukrainian, English and German languages. The author points out that communicative rank and taxonomic class of analyzed actants Content and Experiencer are the same. It is stated and analyzed specific characteristics of the implementation of predicate-actant relations for thematic group of predicates to define the irrational behavior within the irrational situation in the Ukrainian, English and German languages. The paper defines following research of semantic structures of irrational vocabulary to analyze specifiers of the mentioned thematic group of irrational predicates in the Ukrainian, English and German languages.

Key words: predicate-actant relations, predicate-actant modeling, functional syntax, semantic role, syntactical role, syntactical expression, communicative rank, taxonomic class. 